\title{
Agriculture and snakebite in Bahia, Brazil - An ecological study
}

\author{
Yukari Figueroa Mise', Rejâne Maria Lira-da-Silva', Fernando Martins Carvalho' \\ ${ }^{1}$ Federal University of Bahia, Brazil
}

Mise Y F, Lira-da-Silva R M, Carvalho F M. Agriculture and snakebite in Bahia, Brazil - An ecological study. Ann Agric Environ Med. 2016; 23(3): 416-419. doi: 10.5604/12321966.1219179

\section{Abstract}

This study investigated the correlation between the incidence of snakebite and indicators of agricultural development in municipal districts of the State of Bahia, Brazil. An ecological study was conducted with the 27,347 cases of snakebite poisoning reported to the Reportable Diseases National Information System in municipalities from the State of Bahia, Brazil, 2000-2009. The unit of analysis was each one of the 417 State municipalities, and the outcome variable was the average annual incidence of snakebite. Data were analyzed by multiple linear regression technique. The average annual incidence of snakebite ranged from zero to 221.96 per 100,000 inhabitants, according to the municipalities. The incidence of snakebite was positively and strongly associated with municipality characteristics: planted areas of cocoa and coffee, and the size of domestic bred chicken and bovine livestocks. It was concluded that several characteristics related to municipal agricultural profile were strongly associated with the incidence of snakebite.

\section{Key words}

Snake bites, agriculture, incidence.

\section{INTRODUCTION}

Poisoning by snakebite has worldwide reach and affects mainly farm workers in developing countries [1]. It is a serious public health problem due to its incidence, and the severity of poisoning depends on the different types of snakes inhabiting certain environments. It is estimated that annually there are over 500,000 cases of snakebite and around 130,000 deaths (26\%) worldwide [2]. In Brazil, the Ministry of Health estimates the occurrence of 27,000 cases every year [3].

Epidemiological investigations have advanced the knowledge on the profile of the patient victim of snakebite. However, most epidemiological studies on snakebite related accidents carried out in Brazil in the last 100 years have been limited to analysing the same variables as those investigated by Vital Brazil in 1905: gender and age of the victim, month the accident occurred, position of the bite, genus of the snake, time delay between accident and medical assistance and evolution [4].

Although many studies declare that snakebite envenomation affects predominantly rural workers $[5,6,7,8]$, few researchers have evaluated the association between agriculture and the incidence of snakebite. Mortality rates from 138 countries were strongly related to indicators of poverty, including the percentage of labour force in agriculture [1].

The low level of education and income constitute predictors of snakebite in the State of Rio de Janeiro [4]. An investigation about the impact of agribusiness in the State of Mato Grosso, Brazil, reported that the variable 'number of bovine cattle/ number of inhabitants' was strongly associated with the incidence of snakebite. The respective determination coefficient $\left(\mathrm{R}^{2}\right)$ for this correlation was 0.935 , meaning that this variable explained $93.5 \%$ of the variation in the incidence of snakebite [9].

Address for correspondence: Fernando M. Carvalho, School of Medicine, Federal University of Bahia, Largo do Terreiro de Jesus, s/n. Centro Histórico 40026-010 Salvador, Bahia, Brazil.

E-mail: fmc.ufba@gmail.com

Received: 26 March 2016; accepted: 17 May 2016
Analysis of the relationships among socio-economic, occupational and environmental variables and the incidence of snakebite can assist with the definition of prevention and control measures, as well as helping to understand the differential risk between municipal districts. This is fundamental information to guide adequate treatment, as well as the planning and management in health [4].

This study investigated the correlation between the incidence of snakebite and indicators of agricultural development in municipal districts of the State of Bahia, Brazil.

\section{MATERIALS AND METHOD}

In this ecological study, the unity of analysis was each of the 417 municipal districts of State of Bahia which has approximately the same area $\left(564,733 \mathrm{~km}^{2}\right)$ as France. Municipalities populations ranged from 16,353 inhabitants (Madre de Deus) to 2,948,733 inhabitants (Salvador) [10]. Information was obtained through the Ministry of Health about the data related to all cases of snakebite notified to the Reportable Diseases National Information System (SINAN) from January 1, 2000 - December 31, 2009, which occurred in the State of Bahia. Only cases that had all spaces filled, with no loss of information were considered.

The outcome variable corresponded to the annual average incidence of snakebite accidents in municipal districts in Bahia from 2000-2009. The annual incidence coefficient was calculated by dividing the number of cases of snake bites by the population of the municipal district reported by the 2010 Census [10], and expressed by 100,000 inhabitants. The snakebite annual average incidence coefficient for the decade investigated was estimated from the average of all annual incidence coefficients obtained for each municipal district.

The socio-economic and demographic prediction variables analysed were: percentage of municipal area designated for agriculture, percentage of the population employed in agriculture, percentage of the population with access to garbage collection, municipal per capita Gross Domestic 
Product, percentage of illiterates in the population, and population density (inhabitants $/ \mathrm{km}^{2}$ ). Information about socio-economic and demographic variables were obtained from the 2009 and 2010 censuses for the State of Bahia, and respective intercensuses statistical projections [10, 11].

The prediction variables strictly related to agriculture were: cultivated areas of cocoa, banana, coffee, palm oil, coconut, rice, onion, sugar cane, tomato, soya, bean, manioc, corn, and sisal; and the bovine, porcine, equine, chicken (domestic chicken breeding), and industrial farm livestocks. Information about these variables was obtained from the Brazilian Institute of Geography and Statistics [12]

Initially, bivariate analyses evaluated the statistical significance of the correlation and regression coefficients $\left(\beta_{1}\right)$ in order to select the variables for modelling.

The variables that reached the $5 \%$ significance level were selected to compose a set of variables that underwent multiple linear regression analysis. Homoscedasticitywas investigated using the Breusch-Pagan-Godfrey test, and corrected using White's robust correction in order to adjust the standard error from the model heterocedasticy, changing the t statistic. The analysis was conducted with the Stata version 12.0 group of programmes. Partial correlation coefficients and respective significance levels were calculated by using SPSS version 11.0.

A map of the snakebite incidence according to the municipal districts of Bahia was drawn, using the software Tabwin for Windows 3.6.

\section{RESULTS}

In the state of Bahia, from 2000-2009, 27,347 cases of snakebite were notified, corresponding to the coefficient of average annual incidence of 20.2 cases per 100,000 inhabitants.The municipalities with the highest incidence coefficients of snakebite were Pau Brazil - 221.96 cases per 100,000 inhabitants (South Bahia mesoregion), Itagi - 187.43 (Central-South Bahia mesoregion), Itaju do Colônia - 132.09 (South Bahia) and Arataca - 122.23 (South Bahia).

The municipalities with the highest average annual incidences of snakebite were situated in South Bahia and the extreme western mesoregions (Fig. 1).

Bivariate analysis revealed that 12 out of the 25 socioeconomic, demographic and agriculture-related variables investigated showed a correlation coefficient higher than 0.10 , and were statistically associated $(\mathrm{P}<0.05)$ with snakebite incidence (Tab. 1).

Multiple linear regression analysis showed that average annual snakebite incidence was strongly $(\mathrm{P}<0.0000)$ associated with 4 out of the 12 variables in the model: cocoa, coffee, bovine and domestic chicken breeding. The model estimated an average increase of 0.0007028 new cases of snakebite per 100,000 inhabitants per each head of bovine cattle in the period 2000-2009, controlling for the effect of the other variables in the model. This is equivalent to predicting 7,028 new cases of snakebite per 100,000 inhabitants for each 10,000 bovines farmed. The respective partial correlation coefficient for the relationship between snakebite incidence and bovines was $0.297(\mathrm{P}=0.0000)$, controlled by the effects of other variables in the model. The multiple $\mathrm{R}^{2}$ (determination coefficient) was 0.520 , revealing that this set of 12 variables explained $52.0 \%$ of the linear variation of snakebite incidence (Tab. 2).

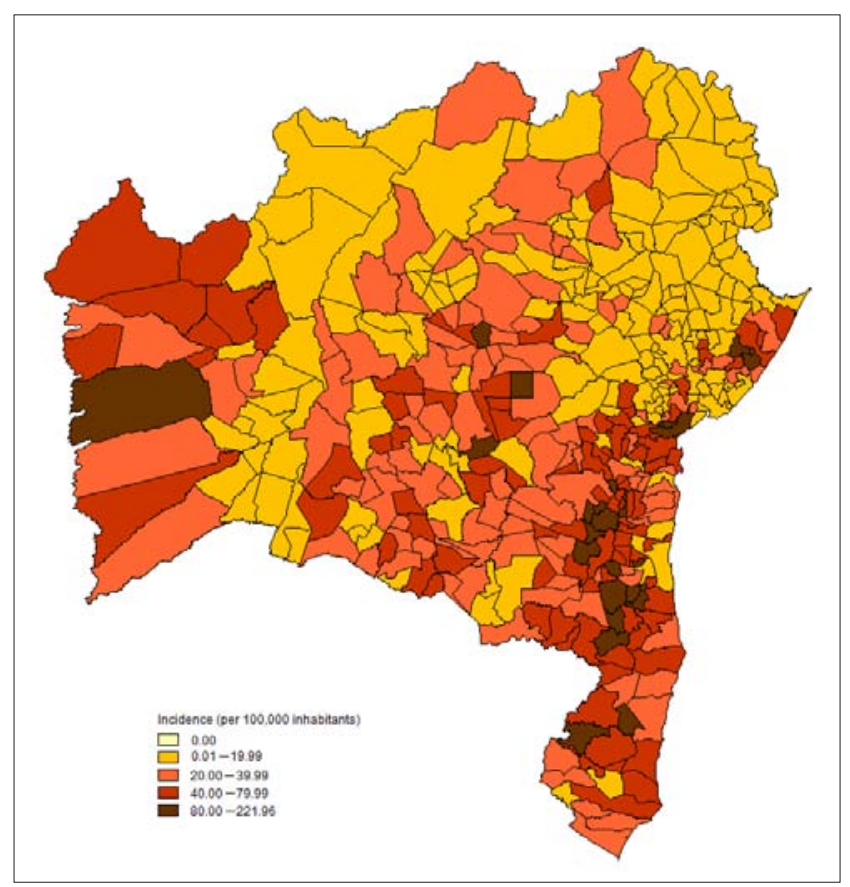

Figure 1. Snakebite average annual incidence coefficient per 100,000 inhabitants in municipal districts of the State of Bahia, Brazil, 2000-2009

\section{DISCUSSION}

Permanent cultivars of coffee and cocoa were statistically associated with snakebite incidence, in accordance with findings from the State of Rio de Janeiro [4]. Harvesting coffee and cocoa demands handling of the fruits. Agricultural workers are more likely to be attacked by a snake on these body parts.

In 2007, the State of Bahia produced 138,000 tons of coffee. The climatic conditions of Bahia impose a non-uniform maturation of the plant, and press towards the use of a larger work force in the coffee ploughing [13]. This contingent of workers demanded by coffee farming, if working without adequate training and use of personal protective equipment, justifies the findings that associate the area reserved for coffee growth with a higher incidence of snakebite.

The cocoa (Theobroma cacao) region in Bahia is integrated into the Atlantic Forest Biome, one of the 25 hotspots of biodiversity in the world, including snakes of medical importance [14]. In Brazil, cocoa is produced in more than 40,000 rural properties distributed in over 150 municipal districts. The 70 municipal districts in the South Bahia Mesoregion produce two-thirds of Brazilian cocoa.

Cocoa is manually harvested. The cocoa farms in Bahia employ an agricultural workforce with a predominant low level of literacy. In the dense forest area considered a hotspot for biodiversity, it is reasonable to expect a high incidence of poisoning by snakebite.

The total number of chicken and bovines were associated with snakebite incidence. Domestic breeding of chicken may have multiple links with snakebites, as chicken have been considered as occasional predators of snakes [15], and the small chicks can also be used as food for these animals, although they are not a part of the preferential diet of the poisonous species in Brazil [16]. This would increase snakes foraging in the farms in search of food, which would increase poisoning by snakebite. Besides that, veterinary poisoning 
Table 1. Bivariate analysis (correlation and regression coefficients and respective $95 \%$ confidence intervals, significance tests and P-values) of snakebite annual incidence (cases by 100,000 inhabitants), according to socio-economic, demographic and agriculture-related variables in Bahia, Brazil, 2000-2009

\begin{tabular}{|c|c|c|c|c|c|c|}
\hline Variables & $\mathrm{R}$ & Regression Coefficient & $95 \%$ Con & Interval & $\mathrm{t}$ & $P$ \\
\hline Cocoa (km² cultivated) & 0,4048 & 0.0070853 & 0.005541 & 0.0086297 & 9.02 & 0.000 \\
\hline Banana (km² cultivated) & 0,2175 & 0.0220231 & 0.0124847 & 0.0315616 & 4.54 & 0.000 \\
\hline Coffee $\left(\mathrm{km}^{2}\right.$ cultivated) & 0,3320 & 0.0147303 & 0.010691 & 0.0187695 & 7.17 & 0.000 \\
\hline Equine $(n)$ & 0,3119 & 0.015705 & 0.0110882 & 0.0203218 & 6.69 & 0.000 \\
\hline Palm oil (km² cultivated) & 0,3119 & 0.016907 & 0.0100504 & 0.0203218 & 4.85 & 0.000 \\
\hline Porcine (n) & 0,1897 & 0.0026037 & 0.0013043 & 0.003903 & 3.94 & 0.000 \\
\hline Chicken, domestic breeding (n) & 0,3387 & 0.0004942 & 0.0003617 & 0.0006268 & 7.33 & 0.000 \\
\hline Coconut (km² cultivated) & 0,1393 & 0.01009 & 0.0013043 & 0.003903 & 2.87 & 0.004 \\
\hline Chicken, industrial farm (n) & 0,1149 & 0.0000423 & 0.0000007 & 0.0000777 & 2.36 & 0.019 \\
\hline Rice ( $\mathrm{km}^{2}$ cultivated) & 0,1131 & 0.0170004 & 0.0026113 & 0.0313894 & 2.32 & 0.021 \\
\hline Onion (km² cultivated) & 0,0933 & 0.0279963 & -0.0008407 & 0.0568332 & 1.91 & 0.057 \\
\hline Population employed in agriculture (\%) & 0,0843 & 0.0099898 & -0.0014021 & 0.0213818 & 1.72 & 0.085 \\
\hline Population with garbage collection (\%) & 0,0843 & -0.0171199 & -.0366451 & 0.0024054 & -1.72 & 0.086 \\
\hline Sugar cane (km² cultivated) & 0,0663 & -0.0368916 & -0.0905599 & 0.0167768 & -1.35 & 0.177 \\
\hline Tomato (km² cultivated) & 0,0632 & 0.0870414 & -0.0457089 & 0.2197917 & 1.29 & 0.198 \\
\hline Soya $\left(\mathrm{km}^{2}\right.$ cultivated) & 0,0520 & 0.0050219 & -0.0043335 & 0.0143773 & 1.06 & 0.292 \\
\hline Bean $\left(\mathrm{km}^{2}\right.$ cultivated $)$ & 0,0424 & -0.0009313 & -0.0030481 & 0.0011856 & -0.86 & 0.388 \\
\hline Manioc (km² cultivated) & 0,0346 & 0.0083924 & -0.0145565 & 0.0313412 & 0.72 & 0.473 \\
\hline Illiteracy (\%) & 0,0332 & -0.4574725 & -1.787867 & 0.8729223 & -0.68 & 0.499 \\
\hline Per capita Gross Domestic Product & 0,0141 & 0.0000574 & -0.0003419 & 0.0004567 & 0.28 & 0.778 \\
\hline Population density (inhab./km²) & 0,0100 & 0.0035197 & -0.026448 & 0.0334874 & 0.23 & 0.818 \\
\hline Corn $\left(\mathrm{km}^{2}\right.$ cultivated) & 0,0100 & 0.0001433 & -.0012647 & 0.0015514 & 0.20 & 0.841 \\
\hline
\end{tabular}

Table 2. Results of multiple linear regression analysis (partial correlation and regression coefficients and respective $95 \%$ confidence intervals, significance tests and P-values) of snakebite annual incidence (cases by 100,000 inhabitants), according to agriculture-related variables in Bahia, Brazil, 2000-2009

\begin{tabular}{|c|c|c|c|c|c|c|}
\hline \multirow{2}{*}{$\frac{\text { Variables }}{\text { Cocoa }\left(\mathrm{km}^{2} \text { cultivated) }\right.}$} & \multirow{2}{*}{$\begin{array}{c}\text { Partial R } \\
0.482\end{array}$} & \multirow{2}{*}{$\begin{array}{c}\text { Regression Coefficient } \\
0.0071208\end{array}$} & \multicolumn{2}{|c|}{ 95\% Confidence Interval } & \multirow{2}{*}{$\frac{t}{6.36}$} & \multirow{2}{*}{$\frac{P}{0.000}$} \\
\hline & & & 0.0049192 & 0.0093223 & & \\
\hline Coffee (km² cultivated) & 0.302 & 0.0102025 & 0.0050534 & 0.0153516 & 3.90 & 0.000 \\
\hline Bovine (n) & 0.297 & 0.0007028 & 0.0003925 & 0.0010131 & 4.45 & 0.000 \\
\hline Chicken, domestic breeding (n) & 0.318 & 0.000364 & 0.0002104 & 0.0005176 & 4.66 & 0.000 \\
\hline Equine (n) & 0.144 & 0.0075291 & -0.0002833 & 0.0153415 & 1.89 & 0.059 \\
\hline Agricultural area (\%) & 0.122 & 0.0830539 & -0.008451 & 0.1745588 & 1.78 & 0.075 \\
\hline Coconut (km² cultivated) & 0.082 & 0.0042056 & -0.0007245 & 0.0091358 & 1.68 & 0.094 \\
\hline Banana (km² cultivated) & 0.062 & 0.0048512 & -0.0028989 & 0.0126014 & 1.23 & 0.219 \\
\hline Chicken, industrial farm (n) & 0.043 & 0.0000114 & -0.0000152 & 0.000038 & 0.84 & 0.399 \\
\hline Rice $\left(\mathrm{km}^{2}\right.$ cultivated) & 0.069 & 0.002774 & -0.0040917 & 0.0096398 & 0.79 & 0.427 \\
\hline Constant (cases/100,000 inhabs.) & - & 17.92632 & 7.346429 & 28.50621 & 3.33 & 0.001 \\
\hline
\end{tabular}

Model $R^{2}=0.520$ 
associated to equine, caprine and bovine have been reported, suggesting the co-occurrence of these animals in areas dedicated to agriculture [17]. In Africa, there are 10 times more incidence of snakebites in people working in industrial plantations than in closed village plantations; this is because snakes are attracted by prey that abound in the former [18].

Grasslands constitute underbrush, and therefore are less likely to accommodate snakes [4]. However, the degradation of snakes original habitat can cause the widening of their geographical distribution because of high ecological plasticity, causing poisoning in areas not previously thought as promising. In Bahia, the species most commonly occurring is Bothrops leucurus, a snake with high environmental plasticity, which can explain the occupation of this species in different niches, including those urbanized [19].

High incidences coefficients of snakebite were found in the municipal districts of Pau Brazil, Itaju do Colônia, Itagi, Itagibá and Aiquara, situated in the South Bahia Mesoregion, which have agriculture and cocoa products as their main economic activities. The economy of Pau Brazil relies on bovine farming, considered a risk factor for snakebite.

Further investigation is needed about the cocoa and coffee cultures as risk factors for snakebites. Further research should also address, besides the size and type of the domestic bred chicken and bovine flocks in each municipality, the breeding and feeding habits the animals, once these agriculture-related characteristics are associated with snakebite incidence.

The true incidence of snakebite envenoming in the State of Bahia, as in most parts of the tropics, remains largely unknown [20]. This fact could have been underestimated, or even have biased the presented results. Despite the methodological limitations inherent in the ecological design, this study demonstrates that the incidence of snakebite is strongly associated with several characteristics related to the municipal agricultural profile.

\section{REFERENCES}

1. Kasturiratne A, Wickremasinghe AR, de Silva N, et al. The global burden of snakebite: a literature analysis and modelling based on regional estimates of envenoming and deaths. PLoS Med. 2008; 5(11): e218. doi: 10.1371/journal.pmed.0050218.
2. Gutiérrez JM, Williams D, Fan HW, et al. Snakebite envenoming from a global perspective: Towards an integrated approach. Toxicon. 2010; 56: $1223-1235$.

3. Cupo, P. Bites and stings from venomous animals: a neglected Brazilian tropical disease. Rev Soc Bras Med Trop. 2015; 48(6): 639-641.

4. Bochner R, Struchiner CJ. Aspectos ambientais e sócio-econômicos relacionados à incidência de acidentes ofídicos no Estado do Rio de Janeiro de 1990 a 1996: uma análise exploratória. Cad Saude Publica. 2004; 20(4): 976-985.

5. Warrell DA. Snake bite. Lancet 2010; 375: 77-88.

6. Praba-Egge AD, Cone SW, Araim O, et al. Snakebites in the rainforests of Ecuador. World J Surg. 2003; 27(2): 234-240.

7. Kularatne AM, Silva A, Maduwage K, et al. Victims' response to snakebite and socio-epidemiological factors of 1018 snakebites in a tertiary care hospital in Sri Lanka. Wilderness Environ Med. 2014; 25(1): 35-40.

8. Sharma SK, Koirala S, Dahal G, et al. Clinico-epidemiological features of snakebite: a study from Eastern Nepal. Trop Doct. 2004; 34(1): 20-22.

9. Pignati WA, Machado JMH. O agronegócio e seus impactos na saúde dos trabalhadores e da população do estado de Mato Grosso. In: Gomes CM, Machado JMH, Pena PGL, eds. Saúde do trabalhador na sociedade brasileira contemporânea. 1st ed. Rio de Janeiro: Fiocruz 2011; p. 245-272.

10. IBGE. Censo Demográfico. OExtremo Oeste Baiano, Mesorregião do Sul Baiano, Mesorregião do Nordeste Baiano e Mesorregião Metropolitana de Salvador, 2010. http://censo2010.ibge.gov.br/ (accessed September 12,2013).

11. Bahia. Anuário Estatístico da Bahia. Superintendência de Estudos Econômicos e Sociais da Bahia. Salvador: SEI; 2009. 691 p.

12. Instituto Brasileiro de Geografia e Estatística (IBGE). Censo Agropecuário2006. IBGE,2007.http://www.ibge.gov.br/home/ estatistica/economia/agropecuaria/censoagro/ (accessed August 3, 2013).

13. Café AABI. Estatística de produção e exportação mundial de café, 2008. http://www.abic.com.br/estat_exportacoes.html (accessed May 3, 2016).

14. Argôlo AJS. As serpentes dos cacauais do sudeste da Bahia. Ilhéus: Editus; 2004.

15. Soerensen B. Acidentes por animais peçonhentos. Reconhecimento, clínica e tratamento. $2^{\text {nd }}$ ed, São Paulo: Editora Atheneu; 2000

16. Bernarde PS, Abe AS. Hábitos alimentares de serpentes em Espigão do Oeste, Rondônia, Brasil. Biota Neotrop. 2010; 10(1): 167-173.

17. Tokarnia CH, P. P. A importância dos acidentes ofídicos como causa de mortes em bovinos no Brasil. Pesq Vet Bras. 2006; 26(2): 55-68.

18. Chippaux J M. Snake bite. Appraisal of the global situation. Bull World Health Organ. 1998; 76(5): 515-524.

19. Mise YF, Lira-da-Silva RM, Carvalho FM. Envenenamento por serpentes do gênero Bothrops no Estado da Bahia: aspectos epidemiológicos e clínicos. Rev Soc Bras Med Trop. 2007; 40(5): 569-573.

20. IPEA. Atlas do desenvolvimento humano no Brasil. Rio de Janeiro: Instituto de Pesquisa Econômica Aplicada/Fundação João Pinheiro/ Instituto Brasileiro de Geografia e Estatística/Programa das Nações Unidas para o Desenvolvimento, 2013. http://atlasbrasil.org.br/2013/ pt/home (accessed September 9, 2013). 